\title{
A TIME STUDY IN PRUNING PLANTATION WHITE SPRUCE AND RED PINE ${ }^{1}$
}

\author{
By A. B. BERRY2
}

\section{ABSTRACT}

In a time study at the Petawawa Forest Experiment Station, pruning white spruce to a height of 17 feet took about twice as long as pruning red pine to the same height, owing to differences in the branching habit, length of live crown, and the persistence of the branches of the species. Under present local market conditions, pruning spruce grown in plantations to increase timber quality would be profitable if the operator had access to a market for clear spruce lumber.

\section{INTRODUCTION}

White spruce (Picea glauca (Moench) Voss) is one of the most important lumber species in eastern Canada. In Ontario, for example, spruce sawlogs rank second in cut only to white pine (Pinus strobus L.), and yielded 131 million f.b.m in $1959 .^{3}$ Whereas clear grades of white pine and red pine (Pinus resinosa Ait.) command a considerably higher price than common grades, the range in price of white spruce grades is relatively narrow because the species fails to prune itself naturally, making all spruce lumber knotty to some extent, and hence clear grades are seldom available. The demands for clear spruce lumber are met primarily by Sitka spruce (Picea sitchensis (Bong) Carr.) indicating that a market exists in the east for high quality white spruce if such could be produced. Since white spruce is an important lumber species, perhaps attention should be given to improving its quality by pruning.

The study described in this paper was carried out in plantations at the Petawawa Forest Experiment Station to provide data on branch numbers and sizes, and to show their effects on pruning time of white spruce and the commonly pruned red pine of comparable sizes.

\footnotetext{
${ }^{1}$ Department of Forestry, Canada, Forest Research Branch Contribution No. 568.

'Research Officer, Forest Research Branch, Petawawa Forest Experiment Station, Chalk River, Ontario.

${ }^{8}$ Information supplied by Forest Economics Division, Canada Department of Forestry.
} 


\section{Stands}

\section{Methods}

For this study, suitable trees were considered to be those between 4 and 7 inches d.b.h., of good form, tall enough to permit pruning up to one loglength (17 feet) without greatly curtailing live crown length, and currently growing at least 1.5 feet in height per year. With these criteria as a guide, one plantation of each species was selected. Both stands had been planted 25 years previously at an average spacing of 6 by 6 feet on sod-covered abandoned fields. The soil was a medium to fine aeolian sand.

The red pine were usually larger and less variable than the white spruce. The diameters of the pine varied from 4 to 8 inches, whereas those of spruce ranged from 2 to 8 inches; the pine were 30 to 45 feet tall, and the spruce 24 to 42 feet. Despite the shortness of some of the 4-inch spruce, they were pruned to the full 17 feet to provide the same data for each diameter class.

\section{Pruning}

In each plantation, 40 trees (10 in each of the 4 - to 7-inch diameter classes) were selected and their diameters and heights were measured. The 7-foot, 12-foot, and 17-foot points above ground were marked on each tree to facilitate pruning exactly to these heights. The branches in each whorl were counted and their basal diameters measured.

All branches were pruned flush with the bole by use of a sectional curvebladed pole saw with the handle lengthened as required. Each tree was pruned in three sections to simulate a three-man crew working with saws of different lengths. The first section pruned was from the ground up to 7 feet, the second from 7 to 12 feet, and the third section from 12 to 17 feet. The actual time taken to prune each section was recorded to 0.01 minutes. To minimize differences in rates of work the operators alternated between sections and diameter classes of each species.

In addition to the time study by sections and individual trees, an attempt was made to determine the hourly rate for a normal uninterrupted operation. For this purpose each man pruned for an hour in each species to a height of 17 feet in a single operation.

\section{Stems and Crowns}

\section{RESULTS}

The average height-diameter relafionships of the pruned trees are presented below:

TABLE 1

Average Height by Diameter Classes

\begin{tabular}{ccc}
\hline $\begin{array}{c}\text { D.B.H. elass } \\
\text { (inches) }\end{array}$ & $\begin{array}{c}\text { Red pine } \\
\text { (feet) }\end{array}$ & $\begin{array}{c}\text { White spruce } \\
\text { (feet) }\end{array}$ \\
\hline 4 & 34 & 28 \\
5 & 37 & 33 \\
6 & 40 & 37 \\
7 & 42 & 40 \\
\hline
\end{tabular}

The differences between species in length of live crown and persistence of branches were marked. The average live crown of the white spruce was 
about 60 per cent of tree height while that of the red pine was only 40 per cent. The spruce branches persisted to the ground and were still sound; but the pine had begun to prune itself and the lower branches were in varying degrees of decay and sound branches were not encountered lower than about 8 feet from the ground.

\section{Branch Characteristics}

The average number of branches per pine was 68 compared with 236 for spruce (Table 2). Each had similar numbers of branches larger than 0.5 inches ( 47 pine and 50 spruce) but spruce had many more small branches than pine.

TABLE 2

Average Branch Number, Size, and Pruning Time ${ }^{1}$

\begin{tabular}{|c|c|c|c|c|c|}
\hline \multirow{2}{*}{ Species } & \multicolumn{4}{|l|}{ D.B.H. } & \multirow{2}{*}{$\begin{array}{r}\text { inches } \\
\text { All }\end{array}$} \\
\hline & 4 & 5 & 6 & 7 & \\
\hline \multicolumn{6}{|l|}{ White Spruce } \\
\hline Number of branches & 269 & 232 & 230 & 212 & 236 \\
\hline Average branch size (inches) & .4 & .4 & .4 & .5 & .4 \\
\hline Pruning time per branch (mins.) & .037 & .040 & .041 & .052 & .042 \\
\hline \multicolumn{6}{|l|}{ Red Pine } \\
\hline Number of branches & 68 & 69 & 66 & 68 & 68 \\
\hline Average branch size (inches) & .6 & .6 & .7 & .7 & .7 \\
\hline Pruning time per branch (mins.) & .056 & .055 & .069 & .068 & .062 \\
\hline
\end{tabular}

${ }^{1}$ Based on branches pruned from 40 trees of each species.

The number of branches per tree decreased with an increase in diameter for spruce, but remained constant for all sizes of pine. The main reason for this was that the smaller diameter spruce took one or two years more to reach a height of 17 feet, resulting in additional whorls, but height growth of the pine was about the same for all trees regardless of diameter.

In general the larger branches were on the larger trees. The average branch was larger on the pine than on the spruce because of the latter's many small internodal branches. The number of branches per foot of pruned bole decreased with an increase in tree diameter and height above ground for the spruce, but remained about the same for all diameter classes of pine.

\section{Pruning Times}

The pruning time per foot of bole is shown in Figure 1. Two things are readily apparent: (a) spruce take longer to prune than pine. (b) unit pruning time usually increases with height and tree diameter. The average time required to prune pine to a height of 17 feet was 4.2 minutes compared with 9.9 minutes for spruce (Table 3). 


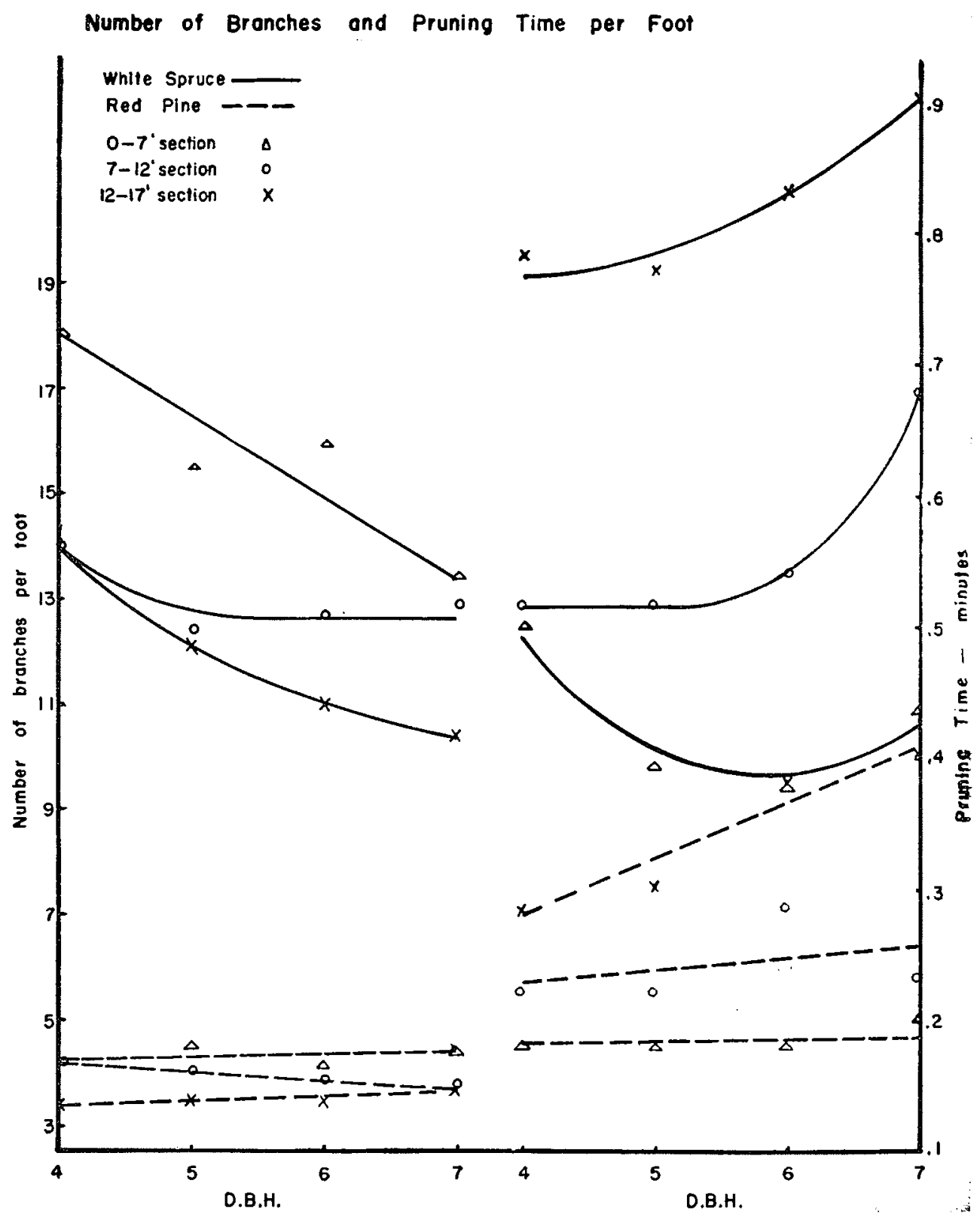

FIGURE 1. Number of branches and pruning time per foot. 
TABLE 3

Pruning Time in Minutes for Red Pine (rP) and White Spruce (wS) by Diameter Classes and Sections above Ground Level ${ }^{2}$

\begin{tabular}{|c|c|c|c|c|c|c|c|c|}
\hline \multirow{2}{*}{$\begin{array}{l}\text { D.B.H. } \\
\text { inches }\end{array}$} & \multicolumn{2}{|c|}{$0-7 \mathrm{ft}}$. & \multicolumn{2}{|c|}{ 7-12 ft. } & \multicolumn{2}{|c|}{$12-17 \mathrm{ft}}$. & \multicolumn{2}{|c|}{$0-17 \mathrm{ft}}$. \\
\hline & $\overline{\mathrm{wS}}$ & $r P$ & $\mathrm{WS}$ & $\mathrm{rP}$ & WS & $r P$ & $\mathrm{wS}$ & $\mathrm{rP}$ \\
\hline 4 & 3.52 & 1.27 & 2.54 & 1.14 & 3.90 & 1.41 & 9.96 & 3.81 \\
\hline 5 & 2.74 & 1.23 & 2.57 & 1.10 & 3.84 & 1.50 & 9.15 & 3.83 \\
\hline 6 & 2.64 & 1.23 & 2.71 & 1.42 & 4.14 & 1.90 & 9.49 & 4.54 \\
\hline 7 & 3.05 & 1.38 & 3.39 & 1.17 & 4.51 & 2.04 & 10.95 & 4.60 \\
\hline Average & 2.98 & 1.28 & 2.81 & 1.20 & 4.10 & 1.71 & 9.89 & 4.19 \\
\hline
\end{tabular}

${ }^{1}$ Times do not include travel time between trees, or delays of any kind.

The pruning times for the first two sections are about the same for each diameter class of each species, but pruning the top section took more time because: (1) the branches on this section are usually larger than on the lower sections for both species and (2) difficulty in manoeuvering and using the pole saw increases with height, particularly for spruce.

In the test to determine hourly pruning rates (including walking time between trees), 8 pine were pruned per hour compared with 4 spruce per hour. This time of approximately 8 minutes per pine agrees with those of Ralston (1953) and ralston and Lemien (1956). This test suggests that pruning plantation spruce would take 15 to 20 minutes a tree.

In a pruning study of red spruce (Picea rubens Sarg.) in natural stands, McLintock (1952) found that the average time (including walking) required to prune to a height of 18 feet, removing approximately 80 branches (over $90 \%$ of which were dead) per tree, was nearly 9 minutes. Although the red spruce had an average diameter roughly the same as that of the white spruce in this study, they had only about a third the number of branches. Also, the red spruce had little or no live crown below 18 feet owing to their having grown in dense natural stands, whereas the height to the live crown of the white spruce was between 13 and 14 feet. If the base of the live crown of the white spruce had been about 17 or 18 feet, the pruning times would probably have been considerably less since live branches are more difficult to prune than dead ones and many of the small internodal branches might have dropped off.

Some natural stands of spruce may have much higher stocking, and hence retain fewer branches per tree for a given age, than spruce grown in plantations at the usual spacings. Hence pruning opportunities in dense natural stands might be more favourable.

\section{Financial Considerations}

Pruning red pine for production of high quality lumber can be worthwhile. Assume for example that the trees are pruned when they are 4 to 7 inches in diameter. At local wage rates and the pruning times found in this study, the average pruning cost would be 20 cents per tree, although this does not allow for minor items of cost such as marking, supervision, depreciation of equipment, etc., which are highly variable. Further, assume 
a carrying charge of 4 per cent per annum, a growth rate of 2 inches per decade and proportions of clear lumber produced as shown by Bickerstaff (1942). The average current local wholesale prices are $\$ 109$ and $\$ 182$ per Mfbm for the best grade of knotty and for clear lumber respectively. Prices vary considerably for different dimensions, but the figures quoted above are for one-inch red pine lumber 4 to 7 inches wide and 6 to 18 feet long. If all trees are harvested when their average diameter is 16 inches, as Smithers (1954) recommends for these sites, the premium of $\$ 73$ per Mfbm for clear lumber would allow a profit of $\$ 3$ to $\$ 5$ per tree. Mortality of pruned trees and the minor costs mentioned above would lower this profit slightly.

But would it be profitable to prune spruce? Spruce takes about twice as long to prune as red pine, and therefore, at local labour rates, the cost would be about 40 cents per tree. This cost of pruning, a 5 -inch tree for example, compounded at 4 per cent for 55 years (at about which time the tree would be 16 inches in diameter) amounts to approximately $\$ 3.50$. To make the pruning operation pay, this cost of $\$ 3.50$ per tree, or about $\$ 40$ per Mfbm, must be recovered as a premium for higher grade lumber. An additional sum must be allowed to pay for losses due to mortality and damage as well as the minor costs of pruning mentioned for pine.

The usual practice is to prune about 20 per cent more trees than are required for the final crop to allow for mortality and damage. But mortality losses should be negligible if a suitable thinning regime is employed.

The local wholesale price for clear spruce is the same as that for red pine, and for knotty grades the price is about $\$ 70$ per $\mathrm{Mfbm}$ which means that high quality spruce lumber commands a premium of over $\$ 100$ per Mfbm. Evidently pruning spruce can be profitable although one point must not be overlooked. Grading of spruce logs is not yet practised in eastern Canada; consequently an operator who prunes his trees receives no premium for high grade material unless he sells the lumber himself or educates buyers as to the value of his logs.

\section{SOMMAIRE ET CONCLUSIONS}

Quarante épinettes blanches et 40 pins rouges mesurant de 4 à 7 pouces de diamètre à hauteur de poitrine, de 28 à 42 pieds de hauteur et formant des peuplements purs ont été émondés jusqu'à une hauteur de 17 pieds en trois étapes. Des observations ont été faites sur le nombre et la grosseur des branches, ainsi que sur la durée de l'émondage.

De cette étude, l'auteur a tiré les conclusions suivantes:

$1^{0}$ En raison des branches internodales, dans les 17 pieds émondés, l'épinette blanche avait 4 fois plus de branches que le pin rouge qui croissait dans des plantations de 25 ans;

$2^{0}$ Les deux essences avaient un nombre analogue de branches ayant à leur base plus de 0.5 pouce re diamètre, mais l'épinette porłait beaucoup plus de petites branches;

$3^{0}$ Le nombre de branches par arbre diminuait à mesure qu'augmentait le diamètre à hauteur de poitrine dans le cas de l'épinette, mais non dans celui du pin; 
$4^{0}$ Les plus grosses branches se trouvaient sur les plus gros arbres;

$5^{0}$ Le nombre de branches par pied de hauteur diminuait en fonction de la hauteur au-dessus du sol pour ce qui est de l'épinette, mais demeurait plus ou moins constant chez le pin;

$6^{0}$ Les branches d'épinette dans la partie supérieure de l'arbre étaient beaucoup plus difficiles à élaguer que celles du pin;

$7^{0}$ En moyenne, il a fallu deux fois moins de temps pour émonder l'épinette que le pin (9.9 minutes par épinette, en comparaison de 4.2 minutes par pin, et 4 épinettes à l'heure en comparaison de 8 pins à l'heure, y compris le temps pour se rendre d'un arbre à l'autre);

$8^{0}$ L'émondage des peuplements d'épinette blanche en. vue d'en accroître la qualité peut être rentable lorsque l'exploitant forestier a directement accès à un débouché pour le bois de sciage, mais si les billes doivent être vendues sur place, il est douteux que les billes de souche puissent se vendre à un coût suffisamment élevé pour couvrir les frais d'émondage;

$9^{0} \mathrm{Il}$ se peut que les peulements naturels denses offrent des conditions qui favorisent quelque peu l'émondage de l'épinette.

\section{REFERENCES}

BICKERSTAFF, A. 1942. The size of tree in pruning. Canada, Mines \& Resources, Dom. For. Serv., Silv. Leaflet No. 9.

McLINTOCK, T. F. 1952. Cost of pruning red spruce in natural stands. J. For. 50: 485-6.

RALSTON, R. A. 1953. Time required to prune red pine to various heights. Lake States For. Exp. Sta. Technical Note No. 391.

RALSTON, R. A. and W. LEMIEN. 1956. Pruning pine plantations in Michigan. Mich. Agric. Exp. Sta. Circ. Bull. No. 221.

SMITHERS, L. A. 1954. Thinning in red and white pine stands at Petawawa Forest Experiment Station. Canada, Northern Affairs \& National Resources, Forestry Branch, For. Res. Div., Silv. Res. Note No. 105. 